\title{
Correction
}

\section{Correction to: DNMT3A reads and connects histone H3K36me2 to DNA methylation}

\author{
Wenqi Xu' ${ }^{1}$, Jiahui $\mathrm{Li}^{1}$, Bowen Rong ${ }^{1}$, Bin Zhao ${ }^{1}$, Mei Wang ${ }^{2}$, Ruofei Dai ${ }^{1}$, Qilong Chen ${ }^{3}$, Hang Liu ${ }^{1}$,

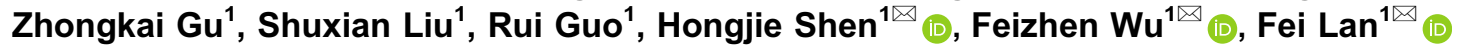 \\ ${ }^{1}$ Key Laboratory of Birth Defects, Children's Hospital, Fudan University, and Key Laboratory of Epigenetics, Institutes of \\ Biomedical Sciences, Fudan University, Shanghai 201102, China \\ 2 Department of Geriatrics, Shanghai General Hospital, Shanghai 201103, China \\ ${ }^{3}$ Research Center for Chinese Traditional Medicine Complexity System, Shanghai University of Chinese Traditional Medicine, \\ Shanghai 201203, China \\ $\bowtie$ Correspondence: hongjieshen@fudan.edu.cn (H. Shen), wufz@fudan.edu.cn (F. Wu), fei_lan@fudan.edu.cn (F. Lan)
}

\section{Correction to: Protein Cell https://doi.org/10.1007/s13238-019-00672-y}

The author would like to add the below information in this correction.

A similar study from Chao Lu group was published online on 5 September 2019 in Nature, entitled "The histone mark H3K36me2 recruits DNMT3A and shapes the intergenic DNA methylation landscape" (Weinberg et al., 2019). Although both studies reported the preferential recognition of H3K36me2 by DNMT3A PWWP, ours in addition uncovered a stimulation function by such interaction on the activity of DNMT3A. On the disease connections, we used a NSD2 gain-of-function model which led to the discovery of potential therapeutic implication of DNA inhibitors in the related cancers, while the other study only used NSD1 and DNMT3A loss-of-function models.

\section{OPEN ACCESS}

This article is licensed under a Creative Commons Attribution 4.0 International License, which permits use, sharing, adaptation, distribution and reproduction in any medium or format, as long as you give appropriate credit to the original author(s) and the source, provide a link to the Creative Commons licence, and indicate if changes were made. The images or other third party material in this article are included in the article's Creative Commons licence, unless indicated otherwise in a credit line to the material. If material is not included in the article's Creative Commons licence and your intended use is not permitted by statutory regulation or exceeds the permitted use, you will need to obtain permission directly from the copyright holder. To view a copy of this licence, visit https:// creativecommons.org/licenses/by/4.0/.

\section{REFERENCES}

Weinberg DN, Papillon-Cavanagh S, Chen H, Yue Y, Chen X, Rajagopalan KN, Horth C, McGuire JT, Xu X, Nikbakht $\mathrm{H}$ et al (2019) The histone mark H3K36me2 recruits DNMT3A and shapes the intergenic DNA methylation landscape. Nature 573:281-286
Wenqi $\mathrm{Xu}$, Jiahui Li and Bowen Rong contributed equally to this work.

The original article can be found online at https://doi.org/10.1007/ s13238-019-00672-y. 